\title{
Guanylin peptides: cyclic GMP signaling mechanisms
}

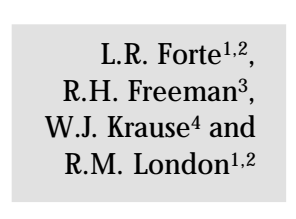

\author{
${ }^{1}$ Harry S. Truman Veterans' Hospital, Departments of \\ ${ }^{2}$ Pharmacology, ${ }^{3}$ Physiology and ${ }^{4}$ Pathology and Anatomical Sciences, \\ School of Medicine, Missouri University, Columbia, MO, USA
}

\section{Correspondence \\ L.R. Forte \\ Department of Pharmacology \\ School of Medicine \\ Missouri University \\ M-515 M edical Sciences Building \\ Columbia, MO 65212 \\ USA \\ Fax: + 1-573-884-4558 \\ E-mail: Irf@ missouri.edu \\ Presented at the Meeting \\ "NO Brazil, Basic and Clinical \\ Aspects of Nitric $O$ xide", \\ Foz do Iguaçu, PR, Brazil, \\ March 10-13, 1999.}

Received May 28, 1999

Accepted June 22, 1999

\section{Abstract}

Guanylate cyclases (GC) serve in two different signaling pathways involving cytosolic and membrane enzymes. Membrane GCs are receptors for guanylin and atriopeptin peptides, two families of cGMPregulating peptides. Three subclasses of guanylin peptides contain one intramolecular disulfide (lymphoguanylin), two disulfides (guanylin and uroguanylin) and three disulfides (E. coli stable toxin, ST). The peptides activate membrane receptor-GCs and regulate intestinal $\mathrm{Cl}^{-}$ and $\mathrm{HCO}_{3}{ }^{-}$secretion via cGMP in target enterocytes. Uroguanylin and $\mathrm{ST}$ also elicit diuretic and natriuretic responses in the kidney. GC-C is an intestinal receptor-GC for guanylin and uroguanylin, but GC-C may not be involved in renal cGMP pathways. A novel receptor-GC expressed in the opossum kidney (OK-GC) has been identified by molecular cloning. OK-GC cDNAs encode receptor-GCs in renal tubules that are activated by guanylins. Lymphoguanylin is highly expressed in the kidney and heart where it may influence cGMP pathways. Guanylin and uroguanylin are highly expressed in intestinal mucosa to regulate intestinal salt and water transport via paracrine actions on GC-C. Uroguanylin and guanylin are also secreted from intestinal mucosa into plasma where uroguanylin serves as an intestinal natriuretic hormone to influence body $\mathrm{Na}^{+}$homeostasis by endocrine mechanisms. Thus, guanylin peptides control salt and water transport in the kidney and intestine mediated by cGMP via membrane receptors with intrinsic guanylate cyclase activity.

\section{Introduction}

Guanylin, uroguanylin and lymphoguanylin are heat-stable peptides that regulate the enzymatic activity of cell-surface guanylate cyclase signaling molecules. Guanylin was the first endogenous peptide identified and was isolated as a 15 amino acid peptide from rat intestine that stimulates cGMP production in T84 intestinal cells (1). Uroguanylin was next isolated from opossum urine as biologically active, 13,14 and 15 amino acid peptides using the T84 cell cGMP bioassay (2). Lymphoguanylin was recently identified using a PCR-based homology cloning strategy to isolate cDNAs from opossum spleen and other lymphoid tissues, which encode a 109 amino acid precursor that is most similar in its primary structure to preprouroguanylin (3). Guanylin and uroguanylin have two intramolecular disulfide bonds, but lymphoguanylin has only one disulfide 
bond. A synthetic form of lymphoguanylin also activates guanylate cyclase (GC)-receptors in human T84 intestinal and opossum kidney (OK) cells. The family of guanylin regulatory peptides share similarities both in primary structures and biological activities with the heat-stable enterotoxin (stable toxin, ST) peptides secreted by strains of enteric microorganisms that cause a watery form of diarrhea similar to that seen in cholera (4). Thus, bacteria-derived ST peptides are molecular mimics of guanylin peptides acting to stimulate fluid and electrolyte secretion into the lumen of the intestine by activation of native guanylin receptors located on the apical surfaces of enterocytes lining the intestine. Biologically active peptides in the guanylin family of proteins are found at the $\mathrm{COOH}$-termini of longer precursor polypeptides that are secreted as biologically inactive prohormones or protoxins (5-8). Proteolytic enzymes serve as converting enzymes to activate the proguanylins or proSTs, but these important enzymes have not been identified thus far.

\section{Physiological actions of guanylin peptides}

Physiological actions of the endogenous guanylin peptides include the regulation of intestinal fluid secretion during digestion, and neutralization of $\mathrm{HCl}$ in the duodenum and of organic acids derived from enteric bacteria in the large intestine $(9,10)$. Guanylins and STs stimulate the electrogenic secretion of both chloride and bicarbonate anions, which provides the physiological driving force to accomplish fluid secretion into the intestinal lumen. Control of these intestinal functions by guanylin peptides is mediated via intracellular cGMP through activation of cGMP-dependent protein kinase II (cG-kinase II) and/or cAMP-dependent protein kinase II (cA-kinase II) with subsequent phosphorylation of the cystic fibrosis transmembrane conductance regulator (CFTR) protein $(11,12)$. CFTR and GC-receptors are localized together in apical plasma membranes of target enterocytes. The first GCreceptor for guanylin family peptides was identified at the molecular level (i.e., GC-C) by molecular cloning of cDNAs encoding an intestinal membrane protein that binds ${ }^{125} \mathrm{I}$ ST with high affinity and is activated by ST (13). Transgenic suckling mice with disabled GC-C genes have a marked reduction in the intestinal fluid secretion response to $E$. coli $\mathrm{ST}$, indicating that GC-C is responsible for a major component of the intestinal actions of guanylin peptides to enhance fluid secretion $(14,15)$. However, about $10 \%$ of specific ${ }^{125}$ I-ST binding to receptor sites on intestinal membranes still remain functional in GC-C-knock out (GC-C-KO) animals (15). This suggests that an additional gene or multiple genes encoding GC-receptors for guanylin agonists exist in the mouse genome.

Bacterial STs were the first peptides shown to activate GC-receptor signaling molecules in the intestine, thus causing secretory diarrhea (4). Moreover, the intestinal GC targets for ST peptides in the intestine were considered unique and not existing outside the intestinal epithelium until we discovered that $E$. coli ST also stimulates GC-receptors found on the surface of OK and potoroo kidney (PtK-2) cell lines (Figure 1 ; Ref. 16). It can be seen from one of our original experiments that these two kidney cell lines have remarkable cGMP responses to $E$. coli $\mathrm{ST}$, but only small cGMP responses to atriopeptin-A and no detectable responses to the nitric oxide donor, sodium nitroprusside. The additional demonstration that kidney cortex has specific GC-receptors that are activated by ST implies that this class of cell surface GC-receptors plays a much broader physiological role in the body than was previously recognized (17-19). It should be emphasized that these findings were made well before the first guanylin peptides were isolated $(1,2)$. Putative "ST 
receptors" were also found in other epithelia of the opossum in addition to the receptors localized to brush border membranes (BBM) of epithelial cells lining the intestinal tract and within renal tubules (16-19). The existence of renal, hepatic, airway and testicular "ST receptors" predicted that endogenous ST-like peptides exist to regulate the activity of the extra-intestinal as well as intestinal GC-receptors. These seminal experiments led directly to the subsequent isolation of guanylin and uroguanylin peptides from intestine and urine, respectively $(1,2)$. Both guanylin and uroguanylin are produced in the intestine, but uroguanylin is the major bioactive peptide found in urine, which contains either no guanylin or very small amounts of the peptide (2,20-22). Uroguanylin and ST stimulate the enzymatic activity of renal tubular GC-receptors and increase the urinary excretion of sodium, potassium and water in both the perfused rat kidney $e x$ vivo and the mouse in vivo (16-19,23-25). Guanylin is less potent in the stimulation of urinary $\mathrm{Na}^{+}$and water excretion compared to either uroguanylin or ST, but guanylin does have marked kaliuretic activity in the perfused rat kidney (24). Thus, uroguanylin has biological activity consistent with a peptide hormone that influences renal function by regulating the urinary excretion of sodium chloride as a physiological mechanism that contributes to the maintenance of $\mathrm{Na}^{+}$ balance in the body. A natriuretic peptide such as uroguanylin was predicted to exist in the digestive system for release into the bloodstream for the purpose of stimulating the urinary excretion of $\mathrm{NaCl}$ following a salty meal $(26,27)$. Uroguanylin is a prime candidate for this "intestinal natriuretic hormone" because it is produced at extraordinarily high concentrations in the upper small intestine and is released following a high salt meal (28-32). Uroguanylin mRNAs are most abundant in the small intestine compared to guanylin mRNA levels, which peak in the large intestine. Uroguanylin and prourogua- nylin are also found in the circulation and it is likely that the gastrointestinal (GI) tract is a main source of the plasma peptides $(7,33$, 34). Secretion of uroguanylin from GI mucosa into the plasma in response to oral $\mathrm{NaCl}$ may explain the prolonged increase in urinary sodium excretion that occurs following a high salt meal $(26,27)$.

\section{Identification of a kidney GC-receptor for uroguanylin}

We sought to elucidate the primary structure of a membrane GC expressed in cultured $\mathrm{OK}$ cells and in the opossum kidney because the prior discovery of this renal GCreceptor was a stimulus that ultimately led to the isolation of guanylin and uroguanylin (1,2,16-19). A PCR-based cloning strategy was used to isolate 3762-bp cDNAs from RNA/cDNAs expressed in OK cells and opossum kidney cortex $(35,36)$. Transfection and expression of the OK-guanylate cyclase (OK-GC) cDNA into COS and HEK293 cells produces a cell surface GCreceptor of $\sim 160 \mathrm{kDa}$ size that is activated by uroguanylin, guanylin and E. coli ST peptides. OK-GC cDNA contains an open reading frame encoding a 1049 residue mature

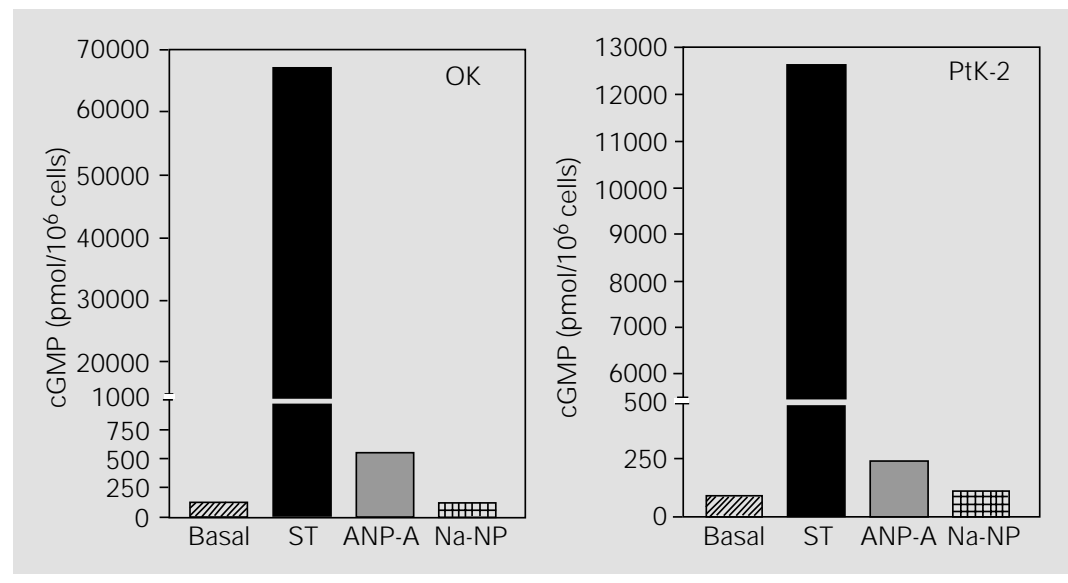

Figure 1 - Activation of surface receptors on OK and PtK-2 cells by Escherichia coli stable toxin (ST) and atriopeptin-A. Confluent cells were treated for $15 \mathrm{~min}$ at $37^{\circ} \mathrm{C}$ in DMEMHEPES-M IX with $0.5 \mu \mathrm{M}$ ST, $0.1 \mu \mathrm{M}$ atriopeptin-A (ANP-A) or $1 \mathrm{mM}$ sodium nitroprusside (Na-NP). The data are reported as the mean of 4 experiments with opossum kidney (OK) cells and 2 experiments with potoroo kidney (PtK-2) cells. 
protein belonging to the family of membrane GC-receptor signaling molecules. OK-GC is similar to other membrane GC proteins containing $\mathrm{NH}_{2}$-terminal agonist-binding domains, a single membrane span and intracellular kinase-like and GC catalytic domains. OK-GC is 72,76 and $75 \%$ identical in its overall structure compared to the intestinal BBM-localized GC-C receptors for guanylin peptides found in rats, humans and pigs, respectively $(13,37,38)$. The catalytic domains of OK-GC and GC-C receptors of rat, human and porcine intestine share 92, 94 and $95 \%$ identity, respectively. The most highly variable region of membrane GCreceptors occurs within the $\mathrm{NH}_{2}$-terminal ligand-binding domains of these proteins. OK-GC shares only $55-59 \%$ identity in this domain when compared to GC-C intestinal receptors for guanylin peptides. The GC-C receptors of the rat are more closely related to human and pig GC-C in the ligand-binding domains with these proteins sharing $70 \%$ identity in this region. Thus, OK-GC is a distinctive renal GC-receptor that, along with the intestinal GC-C receptor, provides two distinctive molecular subtypes of GC-receptors for a growing family of membrane receptors for the guanylin peptides.

OK-GC mRNA levels were measured in total RNA prepared from tissues of opossums by Northern and RT-PCR. A 3.8-kb mRNA was detected in kidney, OK cells, urinary bladder, adrenal gland, heart and intestine. Lower levels of OK-GC mRNA were detected in renal medulla compared to cortex. Tissues with lower levels of OK-GC mRNA are urinary bladder, adrenal gland and both the ventricles and atria of the heart. In the GI tract, high levels of OK-GC mRNA were measured in both the small and large intestine. Thus, OK-GC mRNA is highly expressed in the kidney cortex and intestinal mucosa with mRNA transcripts occurring at lower levels in a number of other organs.

OK-GC is a candidate for the renal tubular receptor that is activated by uroguanylin and/or guanylin peptides that signals via cGMP to regulate the urinary excretion of sodium, potassium and water (23-25). OKGC is the first kidney receptor for guanylin family peptides to be fully defined at the molecular level. Prior to the identification of GC-receptor signaling molecules for $E$. coli ST in the OK and PtK-2 cells and in the opossum kidney, it was thought that STstimulated GCs were restricted to intestinal mucosa (16-19). Thus, identification of OKGC in OK cells and opossum kidney opened up a new field of inquiry that culminated recently with the discoveries of guanylin, uroguanylin and lymphoguanylin peptides (1-3). These peptides activate OK-GC and may serve as endogenous agonists for this membrane GC-receptor. The OK cell line has the differentiated properties of renal proximal tubules and receptor autoradiography experiments with ${ }^{125}$ I-ST have clearly shown that specific binding sites for this uroguanylin-like radioligand are found in cells of both convoluted and straight portions of proximal tubules (16-19). High levels of ${ }^{125}$ I-ST-labeled receptors are also found in BBMs isolated from the kidney and intestine, indicating that this GC-receptor is preferentially localized to apical plasma membranes of both kidney and intestinal target cells. It is likely that OK-GC serves as a physiological receptor for uroguanylin, which is the major bioactive guanylin family peptide in urine (2,20-22). However, guanylin was also isolated from opossum urine indicating that this peptide may influence renal function in vivo via cGMP (2). Active uroguanylin and inactive prouroguanylin peptides circulate in plasma, thus providing a source for the urinary forms of bioactive uroguanylin in opossum, human and rat urine (2,20-22). The kidney also expresses uroguanylin and guanylin mRNAs, which offers the possibility that an intra-renal signaling pathway exists for the guanylin peptides as well as providing another potential source of uroguanylin in the urine $(35,39)$. Physi- 
ologically, uroguanylin may regulate kidney function via an endocrine axis linking the intestine to the kidney and/or through an intra-renal paracrine mechanism. Both possibilities involve the activation of OK-GC as a key signaling molecule in renal tubular target cells that possess the guanylate cyclase-cGMP signaling machinery.

\section{Identification of lymphoguanylin}

A third member of the guanylin family of peptides was sought since biologically active uroguanylin peptides were isolated from opossum urine (2). This inquiry culminated in the isolation of cDNAs encoding opossum preprolymphoguanylin, a third and unique member of the guanylin family of endogenous regulatory peptides (3). The identification of lymphoguanylin stems from recent experiments showing that mRNA transcripts for guanylin and/or uroguanylin and their GC-receptors are expressed broadly in tissues of the digestive, renal-urinary, cardiovascular, reproductive, lymphoid-immune and central nervous organ systems $(7,35)$. Moreover, hybridization assays revealed the existence of a novel mRNA transcript that hybridizes with both uroguanylin and guanylin cDNA probes, but is substantially longer than either the 1.2-kb uroguanylin or 0.8 -kb guanylin mRNAs (3). We identified a third guanylin-related mRNA transcript by molecular cloning using a homology cloning strategy based on the PCR with cDNAs isolated from opossum tissues. The deduced polypeptide was named preprolymphoguanylin because the first cDNAs isolated were derived from several different lymphoid organs and the encoded polypeptide is similar in primary structure to preprouroguanylin and preproguanylin (Figure 2). Sequence analyses of multiple independent cDNA clones reveals that the lymphoguanylin cDNA is $92.7 \%$ identical to the corresponding nucleotide sequences for preprouroguanylin reported previously (7). An open read- ing frame within the lymphoguanylin cDNAs encode a 109 amino acid polypeptide that is $84 \%$ identical to preprouroguanylin and $40 \%$ identical to preproguanylin $(7,35)$. At the $\mathrm{COOH}$-terminus of the 109 amino acid preprolymphoguanylin is a 15 amino acid peptide that is $80 \%$ identical to uroguanylin, but shares only $40 \%$ identity with guanylin (Figure 3). Illustrated for comparison are the structures of opossum lymphoguanylin, uroguanylin, guanylin and an E. coli ST peptide, which form three different subclasses of guanylin peptides based on the number of intramolecular disulfides found within the active peptides. A major difference within lymphoguanylin is the tyrosine ${ }^{109}$ residue because guanylins and uroguanylins have

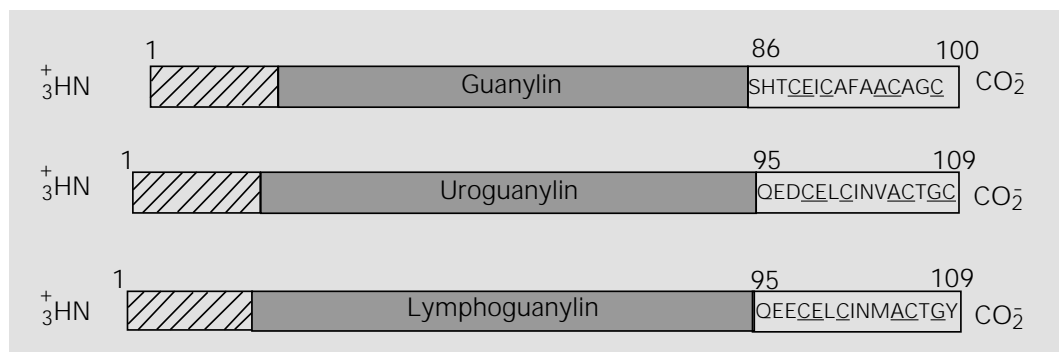

Figure 2 - Prepropeptide structures for guanylin, uroguanylin and lymphoguanylin. The amino acid sequences of the active peptides are shown using the single letter abbreviation of the amino acids within the $\mathrm{COOH}$-terminal regions of each opossum polypeptide.

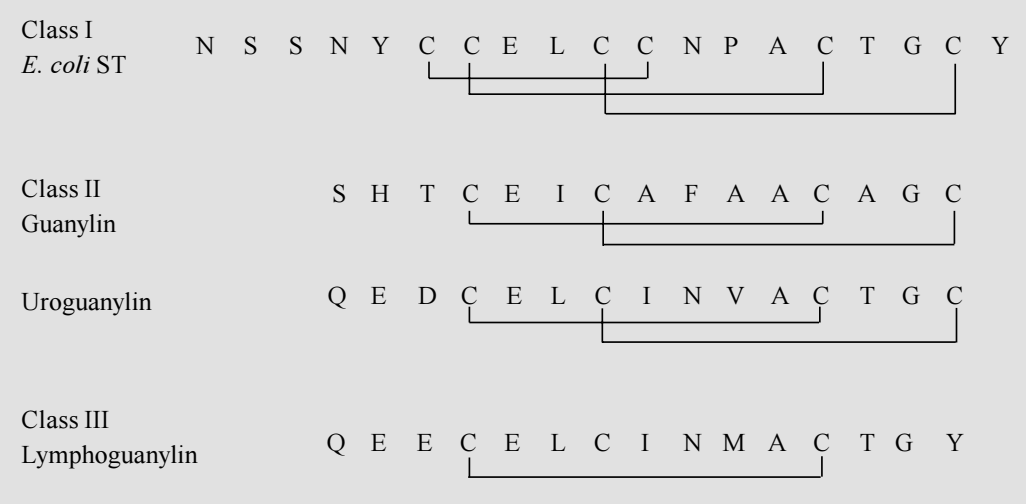

Figure 3 - Comparison of the primary structures of subclasses within the guanylin family of biologically active peptides. The peptide subclasses are provided from top to bottom in the order of their discovery as: Class I peptides containing 3 disulfides, class II peptides with 2 disulfides and class III peptides that have only 1 intramolecular disulfide bond. The single letter abbreviation is used to designate amino acid residues in each peptide. E. coli ST, E. coli stable toxin. 
cysteine residues at this position $(1,2)$. The disulfide bonds formed between the first and third and second to fourth cysteines in the peptide chain were thought to be required for biological activity of guanylin and uroguanylin. The replacement of cysteine ${ }^{109}$ with the tyrosine ${ }^{109}$ residue is a novel molecular change within the guanylin family of peptides. Lymphoguanylin is uroguanylin-like because it has two glutamate residues in its $\mathrm{NH}_{2}$-terminal domain. Opossum uroguanylin has glutamate and aspartate residues and all other uroguanylin molecules in mammalian species have acidic residues at these positions $(2,20,29,30,39)$. Shared between lymphoguanylin and uroguanylin is an internal asparagine residue, which is also found in the bacterial ST peptides. Guanylin peptides have an aromatic amino acid at this position $(1,2,6,7,35)$. The third difference is the methionine ${ }^{104}$ substitution in lymphoguanylin for the valine ${ }^{104}$ of uroguanylin.

A lymphoguanylin peptide was synthesized and oxidized to form an intramolecular disulfide bond between cysteine ${ }^{98}$ and cysteine ${ }^{106}$, with cysteine ${ }^{100}$ protected. Synthetic lymphoguanylin containing a single disulfide stimulates cGMP production in human T84 intestinal cells, but its potency is less than uroguanylin or guanylin (3). All three guanylin peptides are full agonists in the stimulation of intestinal GC-C expressed in human intestinal T84 cells (1-3). When the potencies of these peptides were examined in OK cells, we observed that the OK-GC receptors were also activated by lymphoguanylin.

Lymphoguanylin mRNA transcripts of $\sim 1.6 \mathrm{~kb}$ were detected in total RNA preparations using Northern hybridization assays with a lymphoguanylin cDNA probe (3). Although lymphoguanylin cDNAs were isolated first from lymphoid tissues, we were surprised to discover that tissues with the most abundant lymphoguanylin mRNAs are the atria and ventricles of heart as well as kidney cortex. We also detected $\sim 1.6 \mathrm{~kb}$
mRNAs for lymphoguanylin using Northern assays in RNA from spleen, thymus and testis. Spleen appears to have the most abundant levels of lymphoguanylin mRNA within tissues of the lymphoid/immune system. RTPCR was used to amplify the mRNA-cDNAs of spleen, thymus, lymph nodes, circulating white blood cells, bone marrow, cerebellum and testis. Lymphoguanylin cDNAs were cloned and sequenced to confirm that lymphoguanylin mRNAs are expressed in thymus, lymph nodes, circulating white blood cells, bone marrow, spleen, cerebellum, kidney, OK cells, testis, ovary and heart of the opossum.

\section{Conclusion}

Three different guanylin regulatory peptides, guanylin, uroguanylin and lymphoguanylin, together with their cognate receptors, GC-C and OK-GC, provide signal transduction machinery for cGMP-mediated regulation of cellular function in the kidney, intestine and other epithelia. Combinatorial complexity is achieved by mixing and matching certain subtypes of GC-receptors with cellspecific expression of one or more guanylin peptides for local control of cGMP levels in nearby target cells. A model for this type of local regulation by a paracrine mechanism is best exemplified by the guanylin-cGMP-ion transport mechanisms that have been rigorously demonstrated in the intestinal mucosa. An endocrine axis for uroguanylin serving as an intestinal natriuretic hormone involved in the maintenance of body sodium balance has emerged as well. The recent discovery of lymphoguanylin coupled with evidence that additional subtypes of membrane GC-receptors exist for guanylin peptides suggest that signal transduction pathways utilized by the guanylin family of regulatory peptides are considerably more complicated than previously suspected. It is likely that novel physiological actions of the guanylin regulatory peptides will be discovered as more details 
are learned concerning the cellular and molecular mechanisms of action of these important peptide hormones. Physiological roles for guanylin peptides in the regulation of target cell function via intracellular cGMP are likely to be documented in the future for the immune, reproductive, cardiovascular and central nervous organ systems. This will complement the physiological roles of guanylin and uroguanylin that have been documented thus far in the regulation of fluid and electrolyte transport within the intestine and kidney.

\section{References}

1. Currie MG, Fok KF, Kato J, Moore RJ, Hamra FK, Duffin KL \& Smith CE (1992). Guanylin: an endogenous activator of intestinal guanylate cyclase. Proceedings of the National Academy of Sciences, USA, 89: 947-951.

2. Hamra FK, Forte LR, Eber SL, Pidhorodeckyj NV, Krause WJ, Freeman RH, Chin DT, Tompkins J A, Fok KF, Smith $\mathrm{CE}$, Duffin $\mathrm{KL}$, Siegel NR \& Currie MG (1993). Uroguanylin: structure and activity of a second endogenous peptide that stimulates intestinal guanylate cyclase. Proceedings of the National Academy of Sciences, USA, 90: 10464-10468.

3. Forte $L R$, Eber $S L$, Fan $X$, London RM, Wang $Y$, Rowland LM, Chin DT, Freeman RH \& Krause WJ (1999). Lymphoguanylin: Cloning and characterization of a unique member of the guanylin peptide family. Endocrinology, 140: 1800-1806.

4. Hughes J M, Murad F, Chang B \& Guerrant RL (1978). Role of cyclic GMP in the action of heat-stable enterotoxin of Escherichia coli. Nature, 271: 755-756.

5. Wiegand RC, Kato J \& Currie MG (1992). Rat guanylin CDNA: Characterization of the precursor of the endogenous activator of intestinal guanylate cyclase. Biochemical and Biophysical Research Communications, 185: 812-817.

6. Wiegand RC, Kato J , Huang MD, Fok KF, Kachur J F \& Currie MG (1992). Human guanylin: cDNA isolation, structure and activity. FEBS Letters, 311: 150-154.

7. Fan X, Hamra FK, Freeman RH, Eber SL, Krause WJ , Lim RW, Pace VM, Currie MG \& Forte LR (1996). Uroguanylin: cloning of preprouroguanylin CDNA, mRNA expression in the intestine and heart and isolation of uroguanylin and prouroguanylin from plasma. Biochemical and Biophysical Research Communications, 219: 457462.

8. Hill O, Cetin Y, Cieslak A, Magert H-J \& Forssmann W-G (1995). A new human guanylate cyclase-activating peptide (uroguanylin): precursor cDNA and colonic expression. Biochimica et Biophysica Acta, 1253: 146-149.

9. Guba $M$, Kuhn $M$, Forssmann W-G, Classen M, Gregor M \& Seidler U (1996). Guanylin strongly stimulates rat duodenal $\mathrm{HCO}_{3}{ }^{-}$secretion: proposed mechanism and comparison with other secretagogues. Gastroenterology, 111: 15581568.

10. J oo NS, London RM, Kim HD, Forte LR \& Clarke LL (1998). Regulation of intestinal $\mathrm{Cl}^{-}$and $\mathrm{HCO}_{3}-$ secretion by uroguanylin. American J ournal of Physiology, 274: G633-G644.

11. Pfeifer A, Aszodi A, Seidler U, Ruth P, Hofmann F \& Fassler R (1996). Intestinal secretory defects and dwarfism in mice lacking CGMP-dependent protein kinase II. Science, 274: 2082-2086.

12. Forte LR, Thorne PK, Eber SL, Krause WJ , Freeman RH, Francis SH \& Corbin JD (1992). Stimulation of intestinal $\mathrm{Cl}^{-}$transport by heat-stable enterotoxin: activation of cAMP-dependent protein kinase by cGMP. American J ournal of Physiology, 263: C607-C615.

13. Schulz S, Green CK, Yuen PST \& Garbers DL (1990). Guanylyl cyclase is a heatstable enterotoxin receptor. Cell, 63: 941948.

14. Schulz S, Lopez MJ, Kuhn M \& Garbers DL (1997). Disruption of the guanylyl cyclase- $C$ gene leads to a paradoxical phenotype of viable but heat-stable enterotoxin-resistant mice. J ournal of Clinical Investigation, 100: 1590-1595.

15. Mann EA, J ump $M L, W u$ J, Yee E \& Giannella RA (1997). Mice lacking the guanylyl cyclase $C$ receptor are resistant to STa-induced intestinal secretion. Biochemical and Biophysical Research Communications, 239: 463-466.

16. Forte LR, Krause WJ \& Freeman RH (1988). Receptors and CGMP signaling mechanism for E. coli enterotoxin in opossum kidney. American J ournal of Physiology, 255: F1040-F1046.

17. Forte LR, Krause WJ \& Freeman RH (1989). Escherichia coli enterotoxin receptors: localization in opossum kidney, intestine and testis. American J ournal of Physiology, 257: F874-F881.

18. White AA, Krause WJ , Turner J T \& Forte LR (1989). Opossum kidney contains a functional receptor for the Escherichia coli heat-stable enterotoxin. Biochemical and Biophysical Research Communications, 159: 363-367.

19. Krause WJ, Freeman $\mathrm{RH} \&$ Forte LR (1990). Autoradiographic demonstration of specific binding sites for $\mathrm{E}$. coli enterotoxin in various epithelia of the North American opossum. Cell and Tissue Research, 260: 387-394.

20. Kita T, Smith CE, Fok KF, Duffin KL, Moore WM, Karabatsos PJ, Kachur J F, Hamra FK, Pidhorodeckyj NV, Forte LR \& Currie MG (1994). Characterization of human uroguanylin: member of the guanylin peptide family. American J ournal of Physiology, 266: F342-F348.

21. Fan X, Hamra FK, London RM, Eber SL, Krause WJ, Freeman RH, Smith CE, Currie MG \& Forte LR (1997). Structure and activity of uroguanylin isolated from urine and intestine of rats. American J ournal of Physiology, 273: E957-E964.

22. Nakazato $M$, Yamaguchi $\mathrm{H}$, Kinoshita $\mathrm{H}$, Kangawa $\mathrm{K}$, Matsuo $\mathrm{H}$, Chino $\mathrm{N} \&$ Matsukura S (1996). Identification of biologically active and inactive human uroguanylins in plasma and urine and their increases in renal insufficiency. Biochemical and Biophysical Research Communications, 220: 586-593.

23. Lima AAM, M onteiro HSA \& Fonteles MC (1992). The effects of Escherichia coli heat-stable enterotoxin in renal sodium tubular transport. Pharmacology and Toxicology, 70: 163-167. 
24. Fonteles MC, Greenberg RN, Monteiro HSA, Currie MG \& Forte LR (1998). Natriuretic and kaliuretic activities of guanylin and uroguanylin in the isolated perfused rat kidney. American J ournal of Physiology, 275: F191-F197.

25. Greenberg RN, Hill M, Crytzer J , Krause WJ , Eber SL, Hamra FK \& Forte LR (1997). Comparison of effects of uroguanylin, guanylin, Escherichia coli heat-stable enterotoxin STa in mouse intestine and kidney: evidence that uroguanylin is an intestinal natriuretic hormone. J ournal of Investigative Medicine, 45: 276-282.

26. Lennane RJ , Peart WS, Carey RM \& Shaw J (1975). Comparison of natriuresis after oral and intravenous sodium loading in sodium-depleted rabbits: evidence for a gastrointestinal or portal monitor of sodium intake. Clinical Science and Molecular Medicine, 49: 433-436.

27. Carey RM (1978). Evidence for a splanchnic sodium input monitor regulating renal sodium excretion in man: lack of dependence upon aldosterone. Circulation Research, 43: 19-23.

28. Kinoshita $\mathrm{H}$, Fujimoto $\mathrm{S}$, Nakazato $M$, Yokota N, Date Y, Yamaguchi H, Hisanaga S \& Eto T (1997). Urine and plasma levels of uroguanylin and its molecular forms in renal diseases. Kidney International, 52: 1028-1034.
29. Li Z, Perkins AG, Peters MF, Campa MJ \& Goy MF (1997). Purification, cDNA sequence, and tissue distribution of rat uroguanylin. Regulatory Peptides, 68: 45-56.

30. London RM, Krause WJ , Fan X, Eber SL \& Forte LR (1997). Signal transduction pathways via guanylin and uroguanylin in the stomach and intestine. American J ournal of Physiology, 273: G93-G105.

31. Nakazato $M$, Yamaguchi $H$, Date $Y$, Miyazato M, Kangawa K, Goy MF, Chino N \& Matsukura S (1998). Tissue distribution, cellular source and structural analysis of rat immunoreactive uroguanylin. Endocrinology, 139: 5247-5254.

32. Miyazato $M$, Nakazato $M$, Matsukura $S$, Kangawa K \& Matsuo H (1996). Uroguanylin gene expression in the alimentary tract and extra-gastrointestinal tissues. FEBS Letters, 398: 170-174.

33. Hess, R, Kuhn M, Schulz-Knappe P, Raida M, Fuchs M, Klodt J , Adermann K, Kaever V, Cetin Y \& Forssmann W-G (1995). GCAP-II: isolation and characterization of the circulating form of human uroguanylin. FEBS Letters, 374: 34-38.

34. Kinoshita $\mathrm{H}$, Fujimoto $\mathrm{S}$, Fukae $\mathrm{H}$, Yokota N, Hisanaga S, Nakazato M \& Eto T (1999). Plasma and urine levels of uroguanylin, a new natriuretic peptide, in nephrotic syndrome. Nephron, 81: 160-164.

35. Fan X, Wang Y, London RM, Eber SL,
Krause WJ, Freeman RH \& Forte LR (1997). Signaling pathways for guanylin and uroguanylin in the digestive, renal, central nervous, reproductive and lymphoid systems. Endocrinology, 138: 46364648.

36. London RM, Eber SL, Visweswariah SS, Krause WJ \& Forte LR (1999). Structure and activity of OK-GC: a kidney receptorguanylate cyclase activated by guanylin peptides. American J ournal of Physiology, 276: F882-F891.

37. de Sauvage FJ , Camerato TR \& Goeddel DV (1991). Primary structure and functional expression of the human receptor for Escherichia coli heat-stable enterotoxin. Journal of Biological Chemistry, 266: 17912-17918.

38. Wada A, Hirayama T, Kitao S, Fujisawa J , Hidaka Y \& Shimonishi Y (1994). Pig intestinal membrane-bound receptor (guanylyl cyclase) for heat-stable enterotoxin: CDNA cloning functional expression, and characterization. Microbiology and Immunology, 38: 535-541.

39. Whitaker TL, Witte DP, Scott MC \& Cohen MB (1997). Uroguanylin and guanylin: distinct but overlapping patterns of messenger RNA expression in mouse intestine. Gastroenterology, 113: 1000-1006. 